\title{
The Paradox of the Fight Against Child Labor in Cote D'Ivoire: the Phenomenon of "Microbes"
}

\author{
Sehi Mahié Rita Madeleine Sisso \\ School of Law Jilin University, 2699 Qianjin Street, Chaoyang, Changchun 130000, China
}

\begin{abstract}
Despite the Ivorian government's efforts to combat trafficking, exploitation and child labor, another kind of child labor is expanding in Ivorian capital. These are groups of young and very young delinquent children who have been terrorists in the popular quarts of Abidjan since the day after the post-election crisis of April 2011. With knives and sometimes guns, they attack anyone. Protected by former rebels according to some sources or by the strongmen of the road stations, they engage as much in the traffic of drugs as in the racket of the drivers of collective taxis (Gbaka). The reaction of the authorities is slow to bear fruit and the inhabitants of the neighborhoods are organizing to do justice themselves.
\end{abstract}

Keywords: Paradox, fight, child labor, Cote d'Ivoire, microbes.

DOI: $10.7176 / \mathrm{JLPG} / 88-15$

Publication date: August $31^{\text {st }} 2019$

\section{Introduction}

Cote d 'Ivoire through its 2012-2014 National Action Plan has demonstrated its commitment to make the fight against trafficking, exploitation and child labor a priority. ${ }^{1}$ As such, efforts have been made to bring innovations innovations in this fight. These innovations have contributed to the reduction of the school drop-out rate among children $(59 \%-71 \%)$ and to the improvement of the living environment of rural populations. ${ }^{2}$ However, this fight being accentuated in the cocoa zones because of the high rate of child victims involved in agriculture (71.7\%), has left a phenomenon to settle in Abidjan. This is the phenomenon of "microbes".

Indeed, Ivory Coast is a country of 23,865,564 inhabitants (2016), half of which is under 20 years old. The city of Abidjan alone has 4,707,404 inhabitants and centers of socio-political violence that has affected the country for more than 10 years ${ }^{3}$ : organized gangs commonly called "microbes", composed of underprivileged youth, aged between 10 and 25 years spread terror. ${ }^{4}$

According to the sociologist Rodrigue Koné, this is a criminal phenomenon of gangs, as it exists in several major cities of the world. ${ }^{5}$ He recalled that this phenomenon is not new with regard to Abidjan, but that the novelty lies in the influence of recent political-military crises. He emphasizes that "it is the consequence of socio-economic marginalization." In the 1990s, the bands competed mainly through sports competitions. ${ }^{6}$ At the the same time, in the neighbourhood of Abobo, a drug trafficker nicknamed Zaadi was one of the first to use the services of children broken family or desolated for its distribution network through the municipalities. ${ }^{7}$

All the observers of the phenomenon agree on the determining influence of the Brazilian film "the city of God", realized in a favela in Brazil where the young hero, Zé Pequeño, ends up imposing himself by the violence in a very poor urban environment: disadvantaged young people from Abidjan identify with this child of the favela and dream of urban heroes reigning in terror.

In addition to the term "microbes", the young people in these bands call themselves "von-von", a term that designates a flying insect whose buzzing deranged. ${ }^{8}$ The origin of these negative calls refers to the intergenerational conflicts that have been playing out in the streets of Abidjan since the 1990s, when the confrontations were at first sporty scholar sliding towards direct violence. This particular phenomenon of gangs of very young children exerting unbridled violence on the streets of working-class neighbourhoods appeared the

\footnotetext{
${ }^{1}$ Republic of Côte d'Ivoire (2012), "National Action Plan 2012-2014 against trafficking,nexploitation and child labor ", adopted on March 28, 28, 2012, http://dominiqueouattara.ci/sites / default / files / Dominique-Ouattara Pan-2012-2014-tpfte-part-narrative_0.pdf.

2 "Child labor" in Cote d'Ivoire from the 2008 Survey of Household Living Standards published in 2010. Page 62.

${ }^{3}$ Atlas of the populations and countries of the world, Ivory Coast, PopulationData.net, 16/11/2016

${ }^{4}$ KOUAME Yao Sévérin, MOLTES Anne, Obstacles to social cohesion and dynamics of violence, involving young people in the urban space, space, Participatory Research Report, Interpeace, Indigo Abidjan July 2015; ADELÉ Alexis, Ivory Coast: ulcerated by the "microbes", the habitants of Abidjan do justice, Le Monde, 04/04/2016.

${ }^{5}$ Koné Fahiraman Rodrigue, sociologist at the Center for Research and Action for Peace, CRAP, is in charge of programs at the NGO Freedom House on the issue of "microbes".

${ }^{6}$ Violent overflows were not uncommon and some are still remembered as the violence of 1993 after the return match in Ghana between Asec of Abidjan (Ivory Coast) and Kotoko of Koumassi (Ghana) to the outcome of which Ivorian players and supporters are attacked. The day after the match, the response is fatal to many Ghanaians residing in the Ivory Coast, who are in turn abused and hunted neighbourhoods where they live and work. Some have returned to Ghana.

${ }^{7}$ Winnie A. (Interview), Essential Question to KONE Fahiraman Rodrigue, Potentials, August 2014.

${ }^{8}$ R.B., Microbes and von-von a Abobo ... The new invisible commando, Bôl'kotch, satirical weekly, 04/06/2014.
} 
day after the post-election crisis of $2011 .^{1}$ And it must be added that they have made it a profession.

Given that this phenomenon appears at a time when Ivory Coast is invested in the fight against child labor, there is a paradox between the fight and this phenomenon in full expansion in Abidjan. Thus, to better understand this phenomenon, this study will highlight its causes, the activities of "microbes" and the different reactions to their aggression.

\section{The causes of the phenomenon of "microbes"}

There are two major causes of the phenomenon of "microbes": the precariousness of the urban environment and violence in the public space.

\subsection{Precariousness of the urban environment}

A pre-report from the NGOs Interpeace and Indigo published in 2015 by the United Nations Development Program (UNDP), the United Nations Children's Fund (UNICEF) and the United Nations Mission in Cote d'Ivoire (UNOCI), highlights the main factors structuring the constant disintegration of social cohesion and nourishing the dynamics of violence that affect disadvantaged youth. This is:

- The political economy of social and rhetorical diversities around identities,

- The recomposition of family structures and the appearance of new models of social success,

- The disruption of the school system, and

- The fight for the control of the economic spaces that are the road stations.

Francis Akindès, professor of sociology at the University of Bouake (Cote d'Ivoire), explains that the employment crisis is an important factor in the despair of Ivorian youth. More than $90 \%$ of jobs are in the informal sector. The incomes are very low and despite strong economic growth since 2012, redistribution is weak and does not contribute to eradicating poverty. The country's human development index ranked 172nd out of 187 in 2015 according to $\mathrm{UNDP}^{2}$, and in $2015,46.3 \%$ of the population lived below the poverty line. ${ }^{3}$

When the socio-economic situation deteriorates, when parents die or fall ill, the older sons of disadvantaged urban families often find themselves in a position of responsibility without having the means to do so. They are therefore pushed to the "trouble" to meet the basic needs of their families. ${ }^{4}$

We can distinguish several life courses of "microbes": those from the ranks of veterans during the posteclectic crisis of 2011, those who were informants during the crisis and those who have integrated these groups just by followers, more recently, especially the youngest. ${ }^{5}$

All of them come from defeated classes, inhabitants of popular or even precarious neighbourhoods, but they are not street children. ${ }^{6}$

\subsection{Violence in the public space}

Violence in public space is observed at two levels. On the one hand, these young people are used by political parties or unions to make strokes and on the other hand, the group effect of "Gbonhi" as it is said in Ivorian jargon.

\subsubsection{The use of "microbes" for strokes}

Since the 1990s, the hooligans and "old fathers" of the ghetto, like the political parties and the unions, have been accustomed to buying the services of henchmen to perform some low works. ${ }^{7}$

Young people are also recruited in the road transport sector, by the "unions"8 to operate "lifts" "or "cash out ${ }^{10 "}$. The bus station then becomes a space of self-promotion of the force. ${ }^{11}$ It is also one of the informal sectors that hires the youngest unemployed. ${ }^{12}$

\footnotetext{
${ }^{1}$ KOUAMÉ Yao Sévérin, Moltes Anne, JULY 2015, op.cit .; AKINDES Francis, documentary film: Ivory Coast: hope for a job, Etiquette com, July 2015; KOUAME S., MMOLTES A., Existence by "gbonhi", Engagement of adolescents and young people known as "microbes" in violence in Abobo, Participatory Research Report, Interpeace, Indigo, Abidjan, February 2017.

${ }^{2}$ Ministry of Foreign Affairs, Presentation of Ivory Coast, France Diplomacy, 13/01/2017

${ }^{3}$ Actualitix, Cote d'Ivoire, Population under the poverty line, 10/01/2017.

${ }^{4}$ KOUAMÉ S., MOLTES A., July 2015, op.cit.

${ }^{5}$ Ibid.

${ }^{6}$ KOUAMÉ S., MOLTES A., February 2017, op.cit.

${ }^{7}$ DE LATOUR Éliane, the ghetto men. Street gangs in Abidjan and San Pedro, Proceedings of social science research, crime of immigration, Volume 129, No. 1, 1999, pages 68-83.

${ }^{8}$ Definition: Grouping of several categories of actors in the transport sector (carriers, vehicle owners, drivers) - according to KOUAMÉ and MOLTES (2017).

${ }^{9}$ Definition: In the transport sector, a tough operation, a punitive descent aimed at dispossessing a rival group from a territory that is under control - according to KOUAMÉ and MOLTES (2017).

${ }^{10}$ Definition: Carrying out or compelling an individual to surrender his property. Or the fact of collecting a tax on an activity, especially in the transport sector, using violence - according to KOUAMÉ and MOLTES (2017).

${ }^{11}$ Winnie A., op.cit.

${ }^{12}$ AKINDES Francis, 2015, op.cit.
} 
Like child soldiers in other countries, young people from disadvantaged neighbourhoods sold their arms and legs to different protagonists of the political-military crisis between 2002 and 2011. Some young people today "microbes" have served in the invisible commando of Abobo, during the battle of Abidjan. ${ }^{1}$

With the years of crises and the collapse of the school system, the school no longer appears as an environment of integration or social cohesion but as a place of confrontation. The powerful Student and School Federation of Cote d'Ivoire (SSFCI) has done much to anchor the culture of violence in the school context as the only path to success and social change. ${ }^{2}$ For "microbes", violence responds to a need to "recompose in the absence of real parental authority and to rebuild oneself based on models of authority and success offered by the street." Violence thus becomes banal and everyday, means to exist to survive in "a universe where marginalization becomes a shared social experience". ${ }^{3}$

Some Ivorian and French journalists mention a certain complicity of former rebels integrated in the Republican Forces of Cote d'Ivoire (FRCI), especially for the youngest among these "microbes", who would be used for the illegal activities of the military. ${ }^{4}$

The complicity or complacency of a certain section of the population is also evoked. In addition to the orders for mobile phones passed to "microbes"5, the attack on the premises of the LGBTI defence association, "Alternative Cote d'Ivoire" on January 25, 2014, was conducted with the help of "microbes" mobilized by the population of the neighbourhood, hostile to this cause. ${ }^{6}$

2.2.2. The dynamics of "gbonhi": a mass subject to exist

The academic Richard Banégas, writes that "the young patriots have profoundly changed the social and political situation. ${ }^{7}$ To weigh in politics, henceforth, it is necessary to prove that one is able to hold the pavement, even if it is by the violence of the militia action [...] each one must consult his "gbonhi ${ }^{81}$ to make his voice heard or see recognizing in "post-conflict" society. The author explains that beyond the simple instrumentalisation, the resort to organized gang violence constitutes a new mode of socialization, breaking with the social and traditional hierarchy specific to the urbanity of the working-class neighbourhoods where the political careers are forged in street violence. Thus, the figure of the patriotic militia of the years of the former president has become a model for the underprivileged youth of Abidjan. ${ }^{9}$

The international organization, Interpeace (created by the UN) and its Ivorian partner, the NGO Indigo (Initiative for Dialogue and Research Action for Peace) have also worked on the phenomenon of "microbes" in Abidjan. The February 2017 report establishes that violence through "gbonhi" is perceived as a "social and economic springboard", but that the marginalization suffered by these young people reinforces their identity withdrawal and accentuates their distance from a mode of peaceful socialization. ${ }^{10}$

The power of the band leader is established by his brothers of arms by which he gains the respect of his acolytes. The example of Zama is pragmatic. This Abidjan was originally from Burkina Faso. His father was a dreaded marabou in the precarious district of Boribana Attécoubé, partly evicted ${ }^{11}$ in September 2014. He used the reputations of his father to build a mystical image and inspire fear around him. The circumstances of his death can partly be explained by the mystical fear he inspired among his enemies and his lieutenants to be immortal. $^{12}$

\section{Activities of "microbes"}

To study the activities of "microbes", this will be the place to highlight the districts of Abidjan affected by this phenomenon before talking about their mode of operation.

\subsection{The main districts concerned in Abidjan}

The movement of "microbes" took root in the Abobo commune in northern Abidjan, just after the post-election

\footnotetext{
${ }^{1}$ Winnie A., op.cit.

${ }^{2}$ POMPEY Fabienne, MIEU Beaudelaire, Ivory Coast: SSFCI, trade union or mafia? "Jeune Afrique", 08/02/2009, pp.28-30; HRW, "The Best School", Student Violence, Impunity and the Crisis in Cote d'Ivoire, May 2008.

${ }^{3}$ KOUAMÉ S., MOLTES A. February 2017, op., cit.

${ }^{4}$ Winnie A., op., cit.; GRISOT Maureen, a head of "microbes" beheaded in Abidjan, Le Monde, 08/05/2015.

${ }^{5}$ RFI, the young "microbes" assault and fly in Abidjan, 11/08/2014.

${ }^{6}$ YAO Elysée, Abidjan: the president of homosexuals made revelations, Soir Info 31/01/2014

${ }^{7}$ RICHARD Banégas is a teacher and researcher at the Center of African World Studies (CAWS) and his questions focus on issues of citizenship and political violence in West Africa and the Great Lakes. Since 1999, he has been working on youth engagement in the Cote d'Ivoire crisis.

${ }^{8}$ The "gbonhi" is the band, the group or the family in Nouchi, the slang of the suburbs of Abidjan.

${ }^{9}$ BANEGAS Richard, the politics of "gbonhi". Patriotic mobilizations, militant violence and militant quarries in Cote d'Ivoire, Geneses, 4/2010 (number 81), p. 25-44.

${ }^{10}$ KOUAMÉ S., MOLTES A. February 2017, op., cit.

${ }^{11}$ The eviction is the operation by which it is made obligatory for reasons of public utility to the occupants of a land belonging to the public power to evacuate it even if they have cultivated or built.

${ }^{12}$ GRISOT Maureen, op., cit.
} 
crisis. The "microbes" then have their field of action at the district of Adjamé, Attécoubé, Anyama and Yopougon. ${ }^{1}$ Abobo and Yopougon were at the heart of the fighting during the battle of Abidjan in April 2011; Yopougon being considered the stronghold of supporters of the former president, while Abobo was the base of the invisible commando and rebels favourable to Alassane Ouattara current president of Cote d'Ivoire. ${ }^{2}$

The city of Abidjan has many disadvantaged neighbourhoods or neighbourhoods near residential areas or even rich. The World Bank points out that the years of crisis have aggravated the gap between the upper classes and the lower classes. ${ }^{3}$ Increasing inequalities are factors of additional violence. ${ }^{4}$

A dozen gangs of "microbes" have been identified by actors working in the field. The sources quote the gang of Marley, Boribana and warriors. ${ }^{5}$ Two emblematic figures of these gangs nicknamed "Tonneau" and "Ecomog" were arrested in $2014 .^{6}$

\subsection{Their mode of operation}

Bands often have a godfather called General. He controls the groups of "microbes" through his lieutenants: the "front-gbonhi". These are the chiefs of bands who are at the head of the group "microbes".?

The operating mode of "microbes" is characterized by the violence and speed of actions. Some pose as beggars before attacking their victims encircled. They mainly use machetes and clubs. Others simulate street fights to attack passers-by and traders. ${ }^{8}$ The technique used is constant: stay in a group and sow panic to take advantage of the surprise and deprive their victims. Their actions are particularly profitable on holiday days because people have nice clothes and money on them. It also allows them to strengthen their reputation and thus secure their territory. ${ }^{9}$

The sociologist Rodrigue KONÉ mentions the example of an aggression thus scripted on August 16, 2014 in Yopougon where the boss and the customers of a bar of the street were violent and spoiled. There was one death and several injured. ${ }^{10}$

Some attacks took place outside the popular neighbourhoods of the city. Thus, in September 2014, the "microbes" attacked the Cours Lamartine a French school located at Marcory. ${ }^{11}$

In Attécoubé, it is Zama who was mentioned above and his "microbes" who regularly attacked a spot (openair bar) belonging to the chief of staff of the mayor of the commune, Emile Bodje Lidje, whose turnover has collapsed due to these multiples violence. ${ }^{12}$

The sociologist Francis AKINDÈS participated in the production of a documentary film entitled "Phenomenology of criminal violence in Ivorian cities", funded by Canada, he presented in Cote d'Ivoire in March 2016. He then declared that "these young people consider their crimes as a legitimate economic activity. They told us that they would be willing to engage with the jihadists if they made the proposal. The phenomenon is changing little by little, and these kids who used to work with clubs and knives yesterday are now doing it with Kalashnikovs. " 13

\section{The different reactions to the attacks of "microbes"}

there are two reactions in front of "microbes" attacks, the attitude of the authorities and the reaction of the population.

\subsection{The attitude of the authorities}

In summer 2014, the authorities created a specific police brigade to fight against "microbes" in several communes of Abobo, Attécoubé and Adjamé. In addition to raising awareness among families, these units are responsible for locating gangs and destroying "smoking rooms", a place where drugs are supplied. The police can also count on the cooperation and the denunciations of the population of these districts. ${ }^{14}$ And the district

\footnotetext{
${ }^{1}$ KOUAMÉ S., MOLTES A. July 2015, op., cit.; Winnie A., op.cit.

${ }^{2}$ CESSOU Sabine, Ivorian "microbes", sequels of the crisis, Blog du Monde Diplomatique, 26/01/2017.

${ }^{3}$ World Bank, Communiqué, Cote d'Ivoire: World Bank helps poor families by strengthening the social protection system, 29/05/2015.

${ }^{4}$ AFP, Cote d'Ivoire: poverty level "worrying" despite growth, 20 minutes, 11/11/2014; CAGNOLARI Vladimir, apparent calm, persistent tension, growth without reconciliation in Cote d'Ivoire, Le Monde Diplomatique, October 2015, p.6-7.

${ }^{5}$ KOUAMÉ S., MOLTES A. July 2015, op., cit.; Winnie A., op.cit

${ }^{6}$ Winnie A., op.cit.; Ouattara Lancina, insecurity in Cote d'Ivoire - 122 "microbes" arrested, 20 years in prison for "Tonneau" et Yacou "l'Ecomog", Le Patriote, 14/08/2014.

${ }^{7}$ KOUAMÉ S., MOLTES A. February 2017, op., cit.

${ }^{8}$ Winnie A., op.cit.

${ }^{9}$ KOUAMÉ S., MOLTES A. February 2017, op., cit., GRISOT Maureen, op., cit.

${ }^{10}$ Winnie A., op.cit.

${ }^{11}$ SARAKA Jo Winner, Abidjan "microbes" attacked a French school, Abidjan TV 30/09/2014.

12 GRISOT Maureen, op., cit

${ }^{13}$ KONÉ Check, Cote d'Ivoire: "microbes" are confiding in the researchers / what they plan to do alongside the jihadists, Inter, 02/04/2016.

${ }^{14}$ OUATTARA Lacina, op., cit.
} 
police chief of Abobo commune displayed his determination to eradicate this phenomenon. ${ }^{1}$

Security forces operate pedestrian patrols and motorized patrols. The Coordination Center for Operational Decisions (CCOD) of the Ministry of the Interior has carried out investigations and spinning mills. ${ }^{2}$

In August 2014, the police announced that they arrested 122 people involved in the violence of "microbes", which were transferred to the House of Arrest and Correction of Abidjan (HACA). The two presented as group leaders were sentenced to 20 years' imprisonment. ${ }^{3}$ But some arrests do not always lead to the prison and as soon as young people recover their freedom of action, they find their bands and resume their activities. This is the case of Zama Attécoubé who was arrested by the police and released before being killed by the population in April $2015 .^{4}$

In December 2014, as part of the Disarmament, Demobilization and Reintegration Agency (DDRA) program, a special section for the reintegration of these children was created in the only children's rehabilitation Center in Dabou, 50 kilometers from Abidjan. ${ }^{5}$

In eight months, the Center welcomed 73 children between the ages of 12 and 18 in two promotions (December 2014 and June 2015). Most of these juvenile delinquents were sent to this Center after their arrest to receive training to learn a trade: mechanics, sewing, carpentry. They also receive courses in first aid and civic education. ${ }^{6}$

However, the true rate of reinsertion is very low. Except for a few apprentices in sewing workshops in Dabou, no child of the first class found paid employment because companies are afraid to hire old "microbes". While waiting for a hole in the mouth, the children stay in the Center. ${ }^{7}$

On 12 August 2015, Claude Larissa Abogny, a 23-year-old student, was murdered in Yopougon. In reprisals, the inhabitants have dumped and beat up three alleged members "microbes". Two are subsequently deceased. The Ivorian police then launched the operation "Disinfection" to secure the city in the run-up to the presidential election in October. In Yopougon the police made about fifty arrests. ${ }^{8}$

In September 2015, the promotion of 1162 young police officers after 18 months of training at the National Police College in Cocody heard from the Ministry of Interior and Security came to decorate them, they should do the fight against "microbes" a priority. ${ }^{9}$

In January 2016, President OUATTARA and the Ministry of Interior and Security invited public opinion to no longer qualify these young people as "microbes", but simply as "unemployed". These statements did not appease the population of neighbourhoods targeted by the violence of these young offenders. ${ }^{10}$

The operation "Sparrow hawk" was launched in May 2016 by the police to rake neighbourhoods targeted by "microbes". In three months more than 11500 young people were questioned of which 250 were referred to the floor. Hundreds of weapons were seized including firearms. 166 "smokehouses" were closed and 2,950 tonnes of cannabis confiscated. ${ }^{11}$

Finally, in November 2016, the president's special advisor, Fidele Sarassoro, indicated that a reintegration program for these young people was under way and that 200 of them had been sent to a Center in M'Bahiakro (Bouake region) to make a return to school, to learn a trade from a master, at the end of a judicial procedure. He also referred to "a fund for helping poor families" to complete this scheme. ${ }^{12}$

\subsection{Reaction of the population}

According to Professor Akindes, the repressive method has shown its limits in the resolution of this phenomenon because "death for these children is a commonplace fact. Killing is a game for them. [...] When one of them is killed or arrested, the gangs are systematically reconstituted with other leaders. "13

Thus, despite the actions of law enforcement agencies, the last major of which dates back to August 2014. The gangs of young offenders continue to spread terror in several neighbourhoods of Abidjan. In the commune of Abobo a vigilance committee has been set up, whose members define themselves as "hunters of microbes": they patrol the night, armed, in the streets and "smoking rooms". From a small number of people at the beginning, patrollers are now about fifty to protect the inhabitants with the aim of arresting these offenders and

\footnotetext{
${ }^{1}$ Winnie A., op., cit.

${ }^{2}$ Winnie A., op., cit., TRAORÉ Hamed (Onuci Fm), phenomenon of “microbes": Commissioner Youssouf Kouyate makes revelations, Abidjan TV, 12/10/2014.

${ }^{3}$ OUATTARA Lacina, op., cit.

${ }^{4}$ GRISOT Maureen, op., cit.

${ }^{5}$ CAPRON Alexandre, Lynching of a leader of the "microbe" gang in Abidjan, and after? Observers, France24, 20/04/2015.

${ }^{6}$ CAPRON Alexandre, "Microbes" of Abidjan, the impossible reinsertion? the observers France24, 08/17/2015

${ }^{7}$ Ibid

${ }^{8}$ CAPRON A., 17/08/2015, op cit.; Ivory Justice, the "microbes" of Abidjan, these "products" of post-electoral crisis, 09/09/2015

${ }^{9}$ KEITA Moussa, National Police Academy - 1162 new police officers to track "microbes", Patriot, 09/09/2015

${ }^{10}$ ADÉLÉ Alexis, op.cit.

${ }^{11}$ CESSOU S. op.cit.

${ }^{12}$ APA (African Press Agency), 200 children "microbes" sent to a socialization Center, 12/11/2016.

${ }^{13}$ KONE Check, op., cit.
} 
taking them to the police. Some document files on the "microbes" that they arrest, compiling the photos of victims to the attention of the police. ${ }^{1}$

Faced with the insufficiency of the actions of the police, the exceeded population reacts by groups of selfdefence to do justice itself. Thus on April 14, 2015, Mamadou Traore said Zama 23 years old, according to sources, at the head of a band of Attécoubé was killed. The young Zama was handcuffed, but the police who had to arrest him, would have delivered him to the popular vengeance. He was beaten with stones, hammer, before being beheaded and burned. ${ }^{2}$

The scene was filmed and went around the social networks. But a few months later, the group was reformed and resumed its activities. ${ }^{3}$

The journalist Maureen Grisot also states that Zama controlled the neighbourhood's "smoking rooms" and that he launched a war against a rival band to extend his territory to a neighbouring neighbourhood, whose members took an active part in his hunt and his murder. ${ }^{4}$

On Tuesday, March 29, 2016, Mamadou Diaby, the new presumptive leader of the gang, nicknamed Pytagore, 18, a student in second class, was put to death with machetes by a crowd in Abobo. His chest was open to the abdomen. ${ }^{5}$

The lieutenants of Pythagoras then launched reprisals before four of theirs were lynched by the population. These killings bring to nine the number of "microbes" killed between early February and the end of March 2016. The cycle of violence does not seem ready to stop. ${ }^{6}$

\section{Conclusion}

To see the campaigns that are made for the fight against child labor in Ivory Coast we would be tempted to say that the child is well protected. Elsewhere, the figures and new voting laws have helped to give a new face to the Ivory Coast which struggled to lead an effective fight against child labor. However, there is a paradox between the satisfactory results of this fight and the expansion of the phenomenon of microbes in Abidjan. Consequence of the post-electoral crisis and the poverty of the populations, the phenomenon of the microbes is today a real danger for the population of Abidjan. The powerlessness of the state to this phenomenon has pushed the population to do justice to self-defence groups organized by neighbourhood.

Thus, faced with this phenomenon, the State has no choice but to take its responsibilities. Since the legal framework is already protective, the State must then:

- Make more efforts to ensure strict enforcement of these laws,

- Also stop using these children to install their power,

- Apply good governance which will contribute to the improvement of the living environment of the families of its underprivileged children.

\section{References}

Republic of Côte d'Ivoire (2012), "National Action Plan 2012-2014 against trafficking, exploitation and child labor ", adopted on March 28, 2012, http://dominiqueouattara.ci/ sites / default / files / Dominique-Ouattara Pan2012-2014-tpfte-part-narrative_0.pdf.

"Child labor" in Cote d'Ivoire from the 2008 Survey of Household Living Standards published in 2010. Page 62 Atlas of the populations and countries of the world, (2016) Ivory Coast, PopulationData.net, 16/11/2016

KOUAME Yao Sévérin, MOLTES Anne, (2015) Obstacles to social cohesion and dynamics of violence, involving young people in the urban space, Participatory Research Report, Interpeace, Indigo Abidjan July 2015; ADELÉ Alexis, Ivory Coast: ulcerated by the "microbes", the habitants of Abidjan do justice, Le Monde, 04/04/2016

Koné Fahiraman Rodrigue, sociologist at the Center for Research and Action for Peace, CRAP, is in charge of programs at the NGO Freedom House on the issue of "microbes".

Violent overflows were not uncommon and some are still remembered as the violence of 1993 after the return match in Ghana between Asec of Abidjan (Ivory Coast) and Kotoko of Koumassi (Ghana) to the outcome of which Ivorian players and supporters are attacked. The day after the match, the response is fatal to many Ghanaians residing in the Ivory Coast, who are in turn abused and hunted neighbourhoods where they live and work. Some have returned to Ghana.

Winnie A. (Interview) (2014), Essential Question to KONE Fahiraman Rodrigue, Potentials, August 2014.

\footnotetext{
CAPRON A.," I am a "microbe" hunter in Abidjan" the observers France24, 29/05/2015

${ }^{2}$ CESSOU S. op.cit.; ADÉLÉ Alexis, op.cit.; Grisot M., op., cit.; CAPRON A., 20/04/2015

${ }^{3}$ ADÉLÉ Alexis, op.cit.

${ }^{4}$ Grisot M., op., cit.

${ }^{5}$ ADÉLÉ Alexis, op.cit.

${ }^{6}$ Grisot M., op., cit.; CAPRON A. 20/04/2015, op., cit.
} 
R.B., Microbes and von-von a Abobo ... The new invisible commando, Bôl'kotch, satirical weekly, 04/06/2014. KOUAMÉ Yao Sévérin, Moltes Anne, (JULY 2015), op.cit .; AKINDES Francis, documentary film: Ivory Coast: hope for a job, Etiquette com, July 2015; KOUAME S., MMOLTES A., Research Report, (2017) Interpeace Indigo, Existence by "gbonhi", Engagement of adolescents and young people known as "microbes" in violence in Abobo, Participatory, Abidjan, February 2017.

Ministry of Foreign Affairs, Presentation of Ivory Coast, France Diplomacy, 13/01/2017

KOUAMÉ S., MOLTES A., July 2015, op.cit.

Ibid.

KOUAMÉ S., MOLTES A., February 2017, op.cit.

DE LATOUR Éliane, the ghetto men. Street gangs in Abidjan and San Pedro, Proceedings of social science research, crime of immigration, Volume 129, No. 1, 1999, pages 68-83.

Definition: Grouping of several categories of actors in the transport sector (carriers, vehicle owners, drivers) according to KOUAMÉ and MOLTES (2017).

Definition: In the transport sector, a tough operation, a punitive descent aimed at dispossessing a rival group from a territory that is under control - according to KOUAMÉ and MOLTES (2017).

Definition: Carrying out or compelling an individual to surrender his property. Or the fact of collecting a tax on an activity, especially in the transport sector, using violence- according to KOUAMÉ and MOLTES (2017).

Winnie A., op.cit.

AKINDES Francis, 2015, op.cit.

Winnie A., op.cit.

POMPEY Fabienne, MIEU Beaudelaire, Ivory Coast: SSFCI, trade union or mafia? "Jeune Afrique", 08/02/2009, pp.28-30; HRW, "The Best School", Student Violence, Impunity and the Crisis in Cote d'Ivoire, May 2008.

KOUAMÉ S., MOLTES A. February 2017, op., cit.

Winnie A., op., cit.; GRISOT Maureen, a head of "microbes" beheaded in Abidjan, Le Monde, 08/05/2015.

RFI, the young "microbes" assault and fly in Abidjan, 11/08/2014.

YAO Elysée, Abidjan: the president of homosexuals made revelations, Soir Info 31/01/2014

RICHARD Banégas is a teacher and researcher at the Center of African World Studies (CAWS) and his questions focus on issues of citizenship and political violence in West Africa and the Great Lakes. Since 1999, he has been working on youth engagement in the Cote d'Ivoire crisis.

The "gbonhi" is the band, the group or the family in Nouchi, the slang of the suburbs of Abidjan.

BANEGAS Richard, the politics of "gbonhi". Patriotic mobilizations, militant violence and militant quarries in Cote d'Ivoire, Geneses, 4/2010 (number 81), p. 25-44.

KOUAMÉ S., MOLTES A. February 2017, op., cit.

The eviction is the operation by which it is made obligatory for reasons of public utility to the occupants of a land belonging to the public power to evacuate it even if they have cultivated or built.

GRISOT Maureen, op., cit.

KOUAMÉ S., MOLTES A. July 2015, op., cit.; Winnie A., op.cit.

CESSOU Sabine, Ivorian "microbes", sequels of the crisis, Blog du Monde Diplomatique, 26/01/2017.

World Bank, Communiqué, Cote d'Ivoire: World Bank helps poor families by strengthening the social protection system, 29/05/2015.

AFP, Cote d'Ivoire: poverty level "worrying" despite growth, 20 minutes, 11/11/2014; CAGNOLARI Vladimir, apparent calm, persistent tension, growth without reconciliation in Cote d'Ivoire, Le Monde Diplomatique, October 2015, p.6-7.

KOUAMÉ S., MOLTES A. July 2015, op., cit.; Winnie A., op.cit

Winnie A., op.cit.; Ouattara Lancina, insecurity in Cote d'Ivoire - 122 "microbes" arrested, 20 years in prison for "Tonneau" et Yacou "l'Ecomog", Le Patriote, 14/08/2014.

KOUAMÉ S., MOLTES A. February 2017, op., cit.

Winnie A., op.cit.

KOUAMÉ S., MOLTES A. February 2017, op., cit., GRISOT Maureen, op., cit.

Winnie A., op.cit.

SARAKA Jo Winner, Abidjan “microbes” attacked a French school, Abidjan TV 30/09/2014.

GRISOT Maureen, op., cit.

KONÉ Check, Cote d'Ivoire: "microbes" are confiding in the researchers / what they plan to do alongside the jihadists, Inter, 02/04/2016.

OUATTARA Lacina, op., cit.

Winnie A., op., cit.

Winnie A., op., cit., TRAORÉ Hamed (Onuci Fm), phenomenon of “microbes": Commissioner Youssouf Kouyate makes revelations, Abidjan TV, 12/10/2014.

OUATTARA Lacina, op., cit. 
GRISOT Maureen, op., cit.

CAPRON Alexandre, Lynching of a leader of the "microbe" gang in Abidjan, and after? Observers, France24, 20/04/2015.

CAPRON Alexandre, "Microbes" of Abidjan, the impossible reinsertion? the observers France24, 08/17/2015

Ibid

CAPRON A., 17/08/2015, op. cit.; Ivory Justice, the "microbes" of Abidjan, these "products" of post-electoral crisis, 09/09/2015

KEITA Moussa, National Police Academy - 1162 new police officers to track "microbes", Patriot, 09/09/2015 ADÉLÉ Alexis, op.cit.

CESSOU S. op.cit.

APA (African Press Agency), 200 children "microbes" sent to a socialization Center, 12/11/2016

KONE Check, op., cit.

CAPRON A.," I am a "microbe" hunter in Abidjan" the observers France24, 29/05/2015

CESSOU S. op.cit.; ADÉLÉ Alexis, op.cit.; Grisot M., op., cit.; CAPRON A., 20/04/2015

ADÉLÉ Alexis, op.cit.

Grisot M., op., cit.

ADÉLÉ Alexis, op.cit.

Grisot M., op., cit.; CAPRON A. 20/04/2015, op., cit. 